\title{
Effects of Foliar Applications of Boron at the Early Vegetative Stages on Plant Growth Parameters of Maize
}

\author{
Ömer Konuşkan ${ }^{1, a, *}$, Mehmet Yalçın,b, Hüseyin Gözübenli ${ }^{1, c}$ \\ ${ }^{1}$ Department of Field Crops, Faculty of Agriculture, Mustafa Kemal University, 31030 Hatay/Antakya, Turkey \\ ${ }^{2}$ Department of Soil Science and Plant Nutrition, Faculty of Agriculture, Mustafa Kemal University, 31030 Hatay/Antakya, Turkey \\ *Corresponding author

\begin{tabular}{l|l}
\hline A R T I C L E I N F O & A B S T R A C T \\
\hline Research Article & $\begin{array}{l}\text { Boron is an important micronutrient for growth and development of crop plants. Plant species differ } \\
\text { in their requirement of boron for growth. This study was conducted to determine the effect of boron } \\
\text { application on the plant characteristics of maize during early leaf stages. The experiments were } \\
\text { conducted in Tel - Kalişagricultural research area at the Mustafa Kemal University in 2015 and } \\
\text { 2016 growing seasons. The field experiments were arranged in a split plot design with three } \\
\text { replications. Four boron dosages (control, } 4,6 \text { and } 8 \text { mg/m }{ }^{2} \text { ) were applied at three growing stages } \\
\text { (V2, V4 and V2V4 (at V2 and V4 stages in two equal parts) as foliar spray. The results revealed that } \\
\text { the effects of foliar application of B were positive but statistically insignificant on plant } \\
\text { Accepted : } 27 / 09 / 2019 \\
\text { characteristics. Further researches should be conducted for suitable boron application time at } \\
\text { different growth stages of maize. }\end{array}$ \\
$\begin{array}{l}\text { Keywords: } \\
\text { Maize }\end{array}$ &
\end{tabular}

Early leaf stage

Foliar boron fertilization

Plant parameters

Growing stages

okonuskan@mku.edu.tr

c@hgbenli@mku.edu.tr

(iD) https://orcid.org/0000-0003-1135-2346
(iD https://orcid.org/0000-0003-4799-5749

b@myalcin@mku.edu.tr (i) https://orcid.org/0000-0002-1690-7681

(c) () (9) This work is licensed under Creative Commons Attribution 4.0 International License

\section{Introduction}

Maize is the most important crop among cereals, which are widely grown throughout the world in subtropical and temperate agroclimatic regions (Lordkaew et al., 2010). Maize is one of the most important cereal crops in Turkey, as well it is one of the most prominent nutrient sources for human consumptions and animal feeding (İlker, 2011; EL Sabagh et al., 2015; Barutcular et al, 2016a; 2016b).

Boron, a metalloid, plays important role in physiological events in human and animal bodies and boron deficiency can cause joint rheumatism for humans (Hunt et al., 1991). Besides, boron is one of the essential micronutrients for growth and development of plants. Boron has important roles on sugar transport, cell wall synthesis, flower and bud formation, RNA metabolism, respiration, pollen tube and seed development of plants. (Marshner, 1995; Nelson and Meinhardt, 2011; Kaur and Nelson, 2015). Boron deficiency is common and boron availability decreases with increasing soil $\mathrm{Ph}$ : expecially in limy soils (Marschner, 1995). Likewise, the use of high amounts of phosphorus and in calcareous soils occur the lack of boron. Boron should not be less than $0.5 \mathrm{mg} \mathrm{kg}^{-1}$ in soils (Kurşun et al., 2016). Boron applications can increase maize yield with low quantities (Horuz and Ozcan, 2017).

Fatty acid composition and grain nutritive values were significantly affected by foliar application of boron at early stages of maize plant (Konuskan et al., 2017; Konuskan, 2018). Kurşun et al. (2016) recorded that yield and yield quality of sunflower were improved by boron applications to soil and leaf. Aydin et al. (2005) indicated that boron and some micronutrients were increased by the application of boron to corn. Aref (2012) stated that foliar and soil applications of boron and zinc increased the iron content of the leaf. Seidel et al. (2015) have reported that boron applications at 30'th day after germination had no effects to the yield and yield components of soybean plant. Palta and Karadavut (2011) reported that some corn varieties increased their yields with boron fertilization. It was emphasized that B had positive effects on some plant traits of wheat (Soylu et al., 2004). It was observed that boron had a positive effect on the oil content, seed formation, 
flowering, maturity, grain weight and biological yield of sunflower (Shahzed et al., 2016). Therefore, the objective of this study was to investigate the effects of foliar boron application on plant growth of maize in early development stages of the plant.

\section{Materials and Methods}

A field experiment was carried out in Mustafa Kemal University, Faculty of Agriculture, Department of Field Crops Tel-Kaliş Research and application area in 2015 and 2016 years. In the experiment, 82 May 70 hybrid maize variety (May Agro) ETIDOT-67 (Disodium octa borate tetrahydrate $(\mathrm{Na} 2 \mathrm{~B} 8 \mathrm{O} 13.4 \mathrm{H} 2 \mathrm{O})$ as a source material of $\mathrm{B}$ were used. In every two years, the experimental areas were plowed deeply in the autumn. Soil preparation was carried out with secondary tillage tools close to sowing time. 8 $\mathrm{kg} / \mathrm{da} \mathrm{N}, 8 \mathrm{~kg} / \mathrm{da} \mathrm{P}_{2} \mathrm{O}_{5}$ and $8 \mathrm{~kg} / \mathrm{da} \mathrm{K}_{2} \mathrm{O}$ mixed into the soil as basal fertilizer. The top dressing of nitrogen $18.4 \mathrm{~kg} \mathrm{~N}$ was applied as urea in the knee height stage. Sowing times were 10 April 2015 in the first year and 5 April 2016 in the second year. Seeds were sown by pneumatic seeder as 14 plant $\mathrm{m}^{-2}$.

The soil fertility levels of the Hatay Amik plain vary considerably. The soil of the research area was slightly alkaline, clayey, saltless and limy and organic matter content was low (Yalçın et al., 2018).

Typical Mediterranean climate dominates the research area in Hatay province and the experiment area has a typical Mediterranean climate. Since there is no precipitation in summer months, irrigations were done during maize growing periods (Table 1).
Each parcel consisted of 4 rows of $5 \mathrm{~m}$ long and three different boron doses were applied to the parcels as 400 $(5.6 \mathrm{~g}), 600(8.4 \mathrm{~g})$ and $800(11.2 \mathrm{~g}) \mathrm{gda}^{-1}$. Boron application times were V2 stage (second leaf collar visible), V4 (4th leaf collar visible) and V2 and V4 (2- 4 leaves with visible collars) stages in two portions. and was made with boron pulveriser. 2 litter water was used for each dose. All the recommended cultural practices and protection procedures were followed during the growth period of the crop.

All measurements and observations were done in the middle two rows of the plots. Measurements and weighing were done from the plants in each area of $7 \mathrm{~m}^{2}$ according to Ülger (1986).

The data were subjected to variance analysis by (ANOVA) using MSTAT-C (1991) software package. Least Significant Difference (LSD) test was used to determine the differences among the treatment means according to Gomez and Gomez (1984).

\section{Results and Discussion}

\section{Plant Height $(\mathrm{pH})$}

The height of plant is an important growth character directly related with the productivity potential of plant. In 2015, the highest PH was achieved by $4 \mathrm{mg} / \mathrm{m}^{2}$ foliar boron application at $\mathrm{V} 2$ and $\mathrm{V} 4$ stages as two portions. The lowest value of PH was measured $4 \mathrm{mg} / \mathrm{m}^{2}$ foliar boron application at V4 stage. In 2016, the highest PH $(238 \mathrm{~cm})$ was determined at $4 \mathrm{mg} / \mathrm{m}^{2}$ boron application at V2 stage and the lowest value of $\mathrm{PH}$ was measured at $6 \mathrm{mg} / \mathrm{m}^{2}$ boron application at $\mathrm{V} 2$ stage.

Table 1 Experimental site climate values of 2015-2016

\begin{tabular}{|c|c|c|c|c|c|c|}
\hline Climate parameters & Years & April & May & June & July & August \\
\hline \multirow{2}{*}{ Maximum Temperature $\left({ }^{\circ} \mathrm{C}\right)$} & 2015 & 31.5 & 39.1 & 36.3 & 38.4 & 42.7 \\
\hline & 2016 & 36.6 & 35.4 & 40.8 & 39.2 & 41.1 \\
\hline \multirow{2}{*}{ Minimum Temperature $\left({ }^{\circ} \mathrm{C}\right)$} & 2015 & 4.4 & 9.5 & 12.8 & 18.5 & 18.4 \\
\hline & 2016 & 4.2 & 9.6 & 13.4 & 18.2 & 20.4 \\
\hline \multirow{2}{*}{ Average Temperature $\left({ }^{\circ} \mathrm{C}\right)$} & 2015 & 15.8 & 22 & 24.6 & 28.2 & 29.4 \\
\hline & 2016 & 19.4 & 21.5 & 26.8 & 28.9 & 29.3 \\
\hline \multirow{2}{*}{ Total Rainfall (mm) } & 2015 & 63.2 & 7 & 0 & 0.2 & 0 \\
\hline & 2016 & 5 & 29.6 & 4.8 & 0 & 0 \\
\hline Relative Humidity (\%) & 2015 & 65.1 & 58.5 & 56.1 & 56.8 & 55.1 \\
\hline
\end{tabular}

Table 2 Average values of plant heights and first cob heights at different foliar boron dosages application at early vegetative stages of maize

\begin{tabular}{|c|c|c|c|c|c|c|}
\hline \multirow{2}{*}{ Plant stages } & \multicolumn{3}{|c|}{ Plant Height $(\mathrm{cm})$} & \multicolumn{3}{|c|}{ First Cob Height $(\mathrm{cm})$} \\
\hline & 2015 & 2016 & Ort. & 2015 & 2016 & Ort. \\
\hline Control & 238 & 233 & 235 & 100 & 90 & 95 \\
\hline $\mathrm{V} 2\left(4 \mathrm{mg} / \mathrm{m}^{2} \mathrm{~B}\right)$ & 241 & 238 & 240 & 105 & 88 & 96 \\
\hline $\mathrm{V} 2\left(6 \mathrm{mg} / \mathrm{m}^{2} \mathrm{~B}\right)$ & 240 & 228 & 234 & 101 & 93 & 97 \\
\hline $\mathrm{V} 2\left(8 \mathrm{mg} / \mathrm{m}^{2} \mathrm{~B}\right)$ & 240 & 231 & 231 & 93 & 96 & 95 \\
\hline $\mathrm{V} 4\left(4 \mathrm{mg} / \mathrm{m}^{2} \mathrm{~B}\right)$ & 231 & 229 & 233 & 96 & 95 & 95 \\
\hline $\mathrm{V} 4\left(6 \mathrm{mg} / \mathrm{m}^{2} \mathrm{~B}\right)$ & 236 & 231 & 234 & 95 & 93 & 94 \\
\hline $\mathrm{V} 4\left(8 \mathrm{mg} / \mathrm{m}^{2} \mathrm{~B}\right)$ & 233 & 235 & 234 & 95 & 90 & 92 \\
\hline $\mathrm{V} 2 \mathrm{~V} 4\left(4 \mathrm{mg} / \mathrm{m}^{2} \mathrm{~B}\right)$ & 243 & 232 & 238 & 100 & 93 & 96 \\
\hline $\mathrm{V} 2 \mathrm{~V} 4\left(6 \mathrm{mg} / \mathrm{m}^{2} \mathrm{~B}\right)$ & 235 & 231 & 233 & 98 & 90 & 94 \\
\hline $\mathrm{V} 2 \mathrm{~V} 4\left(8 \mathrm{mg} / \mathrm{m}^{2} \mathrm{~B}\right)$ & 236 & 237 & 237 & 98 & 93 & 95 \\
\hline Average & $237^{a^{* *}}$ & $233^{\mathrm{b}}$ & & $98.3^{\mathrm{a}^{* *}}$ & $92.3^{\mathrm{b}}$ & \\
\hline $\mathrm{CV}(\%)$ & & 2.13 & & & 4.89 & \\
\hline
\end{tabular}

\footnotetext{
*There is no significant difference between the averages in the same letter group (LSD\% 5)
} 
Table 3 Average values of Grain Weights per Cob and Stem Diameters at different foliar boron dosages application at early vegetative stages of maize

\begin{tabular}{|c|c|c|c|c|c|c|}
\hline \multirow{2}{*}{ Plant stages } & \multicolumn{3}{|c|}{ Grain Weight per Cob (g) } & \multicolumn{3}{|c|}{ Stem Diameter (mm) } \\
\hline & 2015 & 2016 & Average & 2015 & 2016 & Average \\
\hline Control & 225 & 188 & 207 & 18.7 & 21.7 & 20 \\
\hline $\mathrm{V} 2\left(4 \mathrm{mg} / \mathrm{m}^{2} \mathrm{~B}\right)$ & 222 & 193 & 208 & 21.7 & 22.7 & 20.5 \\
\hline $\mathrm{V} 2\left(6 \mathrm{mg} / \mathrm{m}^{2} \mathrm{~B}\right)$ & 234 & 182 & 208 & 18.3 & 21.3 & 20.2 \\
\hline $\mathrm{V} 2\left(8 \mathrm{mg} / \mathrm{m}^{2} \mathrm{~B}\right)$ & 217 & 193 & 205 & 19 & 22 & 20.5 \\
\hline $\mathrm{V} 4\left(4 \mathrm{mg} / \mathrm{m}^{2} \mathrm{~B}\right)$ & 229 & 184 & 206 & 19 & 21.3 & 20.2 \\
\hline $\mathrm{V} 4\left(6 \mathrm{mg} / \mathrm{m}^{2} \mathrm{~B}\right)$ & 240 & 193 & 215 & 19 & 21.7 & 19.7 \\
\hline $\mathrm{V} 4\left(8 \mathrm{mg} / \mathrm{m}^{2} \mathrm{~B}\right)$ & 230 & 199 & 215 & 17.7 & 22.7 & 20.5 \\
\hline $\mathrm{V} 2 \mathrm{~V} 4\left(4 \mathrm{mg} / \mathrm{m}^{2} \mathrm{~B}\right)$ & 220 & 180 & 200 & 18.3 & 21 & 19.7 \\
\hline $\mathrm{V} 2 \mathrm{~V} 4\left(6 \mathrm{mg} / \mathrm{m}^{2} \mathrm{~B}\right)$ & 242 & 198 & 220 & 19.3 & 22.7 & 21 \\
\hline $\mathrm{V} 2 \mathrm{~V} 4\left(8 \mathrm{mg} / \mathrm{m}^{2} \mathrm{~B}\right)$ & 232 & 187 & 209 & 18.7 & 22 & 20.3 \\
\hline Average & $229^{* a}$ & $190^{\mathrm{b}}$ & & $18^{* b}$ & $21.9^{\mathrm{a}}$ & \\
\hline $\mathrm{CV}(\%)$ & & 7.54 & & & 7.17 & \\
\hline
\end{tabular}

* There is no significant difference between the averages in the same letter group (LSD\% 5)

\section{First Cob Height (FCH)}

The data indicated that, the mean FCH in the first year $(98.3 \mathrm{~cm})$ was higher than that of the second year $(92.3$ $\mathrm{cm})$. In 2015, the highest value of FCH was measured at 4 $\mathrm{mg} / \mathrm{m}^{2}$ foliar boron dosages $(105 \mathrm{~cm})$ at V2 stage. The lowest FCH was measured $93 \mathrm{~cm}$ at $8 \mathrm{mg} / \mathrm{m}^{2}$ foliar boron dosages at V2 stage. In 2016, the highest $\mathrm{FCH}$ was determined at $\mathrm{V} 2$ leaf satge period $(96 \mathrm{~cm})$ at $8 \mathrm{mg} / \mathrm{m}^{2}$ foliar boron application and the lowest $\mathrm{FCH}$ was measured at V2 leaf stage period $(88 \mathrm{~cm})$ at $4 \mathrm{mg} / \mathrm{m}^{2}$ boron application. Konuskan and Gözübenli (2001); Konuskan (2000) found that first cob height increased with increasing plant density, whereas the cob length decreased with increasing density.

\section{Grain Weight per Cob (GWC)}

The data regarding the effect of boron application on grain weight per cob of maize (Table 2) revealed that there were increases in grain weights but difference among, there was no significant variances in the mean GWC (Grain Weight per $\mathrm{Cob}$ ) were not statically significant in both years (Table 3). The average GWC of the first year (229 g) was higher than that of the second year (190 g). In 2015, The highest GWC was observed at $6 \mathrm{mg} / \mathrm{da}$ boron dosages applied at V2V4 stages (as two portions) (Table 3). The average of highest grain weight $(240 \mathrm{~g})$. was observed 6 $\mathrm{mg} / \mathrm{da}$ boron application dosages at V2V4 stage. Soylu et al. (2006) reported that boron applications generally affect the weight of the grain and the weight of one thousand, the flag leaf nutrient content. Ziaeyan and Rajaie (2009) found that $\mathrm{Zn}$ and $\mathrm{B}$ fertilization significantly increased grain weight, grain protein content and the concentration of B and $\mathrm{Zn}$ concentrations in corn tissues.

\section{Stem Diameter (SD)}

The data regarding Stem Diameter plant-1 are presented in Table 3 . The results showed that the average SD was $18 \mathrm{~mm}$, and t $19.3 \mathrm{~mm}$ in 2015-2016 respectively, and the average SD the first year was lower than the second year. In the First year, the heights SD values was $21,7 \mathrm{~mm}$ on V2 (2 leaves with visible collars) at foliar boron fertilization $\left(4 \mathrm{mg} / \mathrm{m}^{2}\right)$. The lowest value was $18.3 \mathrm{~mm}$ on $\mathrm{V} 2$ at $6 \mathrm{mg} / \mathrm{m}^{2}$. In Second year, the heights SD values were concluded $22,7 \mathrm{~mm}$ at $\mathrm{V} 2$ by foliar boron fertilization 4 $\mathrm{mg} / \mathrm{m}^{2}$, at $\mathrm{V} 4$ by foliar boron application $8 \mathrm{mg} / \mathrm{m}^{2}$, and $\mathrm{V} 2 \mathrm{~V} 4$ at foliar boron application $6 \mathrm{mg} / \mathrm{m}^{2}$ (half dosage (3 $\left.\mathrm{mg} / \mathrm{m}^{2}\right)$ was applied V2 and half dosage $\left(3 \mathrm{mg} / \mathrm{m}^{2}\right)$ was applied V4) respectively. Shagholi et. All (2013) found that spray the element boron was positive and significant effect on dry matter production of maize.

\section{Cob Length (CL)}

The results regarding cob length presented in Table 4, showed that foliar application of boron at early vegetative stages hadn't significant effect. Both years, there were no statically differences among foliar fertilization dosages at early vegetative stages of maize for the mean CL and CD in 2015. The average cob lengths were $18 \mathrm{~cm}$ in 2015 and $18.5 \mathrm{~cm}$ in 2016 . The highest CL $19.2 \mathrm{~cm}$ was measured at $\mathrm{V} 4$ at $6 \mathrm{mg} / \mathrm{m}^{2}$ boron dose at V4 stage in 2015. The lowest value of CL $17.1 \mathrm{~cm}$ was observed at $8 \mathrm{mg} / \mathrm{m}^{2}$ boron application at V4 stage in 2015. In 2016, While the highest CL was measured as $19.5 \mathrm{~cm}$ at control treatment, the lowest CL was measured as $17.7 \mathrm{~cm}$ at $8 \mathrm{mg} / \mathrm{m}^{2}$ boron dose applied at V2 and V4 stages in two portions. In the study of Konuşkan et al. (2017) reported that the early application of boron corn had significant effects on oil and fatty acid composition of maize and had no effects on starch and protein contents.

\section{Cob Diameter $(C D)$}

Average cob diameters observed as $43.4 \mathrm{~mm}$ in 2015 and $42.5 \mathrm{~mm}$ in 2016. Considering the average of two years the highest CD was measured as $43.5 \mathrm{~mm}$ at $6 \mathrm{mg} / \mathrm{m}^{2}$ boron application at V2 and V4 stages at two portions. The lowest $\mathrm{CD}$ was measured as $42.4 \mathrm{~mm}$ at $8 \mathrm{mg} / \mathrm{m}^{2}$ boron application at V2 and V4 stages as two portions (Table 4). In 2015, the highest CD was measured as $44.1 \mathrm{~mm}$ at 6 $\mathrm{mg} / \mathrm{m}^{2}$ boron dose at V2 and V4 stages. The lowest CD value was measured at $4 \mathrm{mg} / \mathrm{m}^{2}$ boron application at V2 stage. In 2016, the highest CD value was measured as 43 $\mathrm{mm}$ at $6 \mathrm{mg} / \mathrm{m}^{2}$ boron application. The lowest $C D$ value was measured as $41.7 \mathrm{~mm}$ at $8 \mathrm{mg}$ boron application at V2 and V4 stages as two portions. Wasaya et all(2017) recorded that combined foliar application of $\mathrm{B}$ and $\mathrm{Zn}$ improved maize yield in relation to improvements in yield related attributes. 
Table 4 Average values of Cob Lengths and Cob Diameters at different foliar boron dosages application at early vegetative stages of maize

\begin{tabular}{|c|c|c|c|c|c|c|}
\hline \multirow{2}{*}{ Plant stages } & \multicolumn{3}{|c|}{ Cob Length $(\mathrm{cm})$} & \multicolumn{3}{|c|}{ Cob Diameter $(\mathrm{mm})$} \\
\hline & 2015 & 2016 & Average & 2015 & 2016 & Average \\
\hline Control & 18.1 & 19.5 & 18.8 & 43.3 & 42.5 & 42.9 \\
\hline $\mathrm{V} 2\left(4 \mathrm{mg} / \mathrm{m}^{2} \mathrm{~B}\right)$ & 17.4 & 18.9 & 18.2 & 42.5 & 42.4 & 42.5 \\
\hline $\mathrm{V} 2\left(6 \mathrm{mg} / \mathrm{m}^{2} \mathrm{~B}\right)$ & 18.3 & 18.2 & 18.3 & 43.8 & 42.8 & 43.3 \\
\hline $\mathrm{V} 2\left(8 \mathrm{mg} / \mathrm{m}^{2} \mathrm{~B}\right)$ & 17.9 & 18.6 & 18.3 & 43.2 & 42.6 & 42.9 \\
\hline $\mathrm{V} 4\left(4 \mathrm{mg} / \mathrm{m}^{2} \mathrm{~B}\right)$ & 18.6 & 18.2 & 18.4 & 43.9 & 42.7 & 43.3 \\
\hline $\mathrm{V} 4\left(6 \mathrm{mg} / \mathrm{m}^{2} \mathrm{~B}\right)$ & 19.2 & 18.7 & 18.9 & 43.4 & 43 & 43.2 \\
\hline $\mathrm{V} 4\left(8 \mathrm{mg} / \mathrm{m}^{2} \mathrm{~B}\right)$ & 17.1 & 19 & 18.1 & 42.7 & 42.9 & 42.8 \\
\hline $\mathrm{V} 2 \mathrm{~V} 4\left(4 \mathrm{mg} / \mathrm{m}^{2} \mathrm{~B}\right)$ & 18.4 & 18.1 & 18.2 & 43.7 & 42.3 & 43 \\
\hline $\mathrm{V} 2 \mathrm{~V} 4\left(6 \mathrm{mg} / \mathrm{m}^{2} \mathrm{~B}\right)$ & 18.7 & 18.7 & 18.6 & 44.1 & 42.9 & 43.5 \\
\hline $\mathrm{V} 2 \mathrm{~V} 4\left(8 \mathrm{mg} / \mathrm{m}^{2} \mathrm{~B}\right)$ & 17.2 & 17.7 & 17.4 & 42.9 & 41.7 & 42.4 \\
\hline Average & 18 & 18.5 & & $43.4^{\mathrm{a}}$ & $42.5^{\mathrm{b}}$ & \\
\hline CV (\%) & \multicolumn{3}{|c|}{5.60} & \multicolumn{3}{|c|}{1.81} \\
\hline
\end{tabular}

* There is no significant difference between the averages in the same letter group (LSD\% 5)

\section{Conclusions and Recommendations}

These results indicated that boron applications at early growth stages of maize had positive effects on maize plant growth and development, but these increaments were statically insignificant. Further researches are recommended for boron effects on maize plant development at late vegetative stages of maize.

\section{References}

Aref F. 2012. Manganese, iron and copper contents in leaves of maize plants (Zea mays L.) grown with different boron and zinc micronutrients. African Journal of Biotechnology 11(4): 896-903.

Aydın A, Kant C, Ataoğlu N. 2005. Erzurum ve rize yöresi toprak örneklerine uygulanan farklı dozlardaki bor ve fosforon misır (zea mays)'in kuru madde miktarları ve mineral içeriğine etkisi. Atatürk Üniv. Ziraat Fakültesi degisi, 36(2): 125-129.

Barutcular C, Sabagh AE, Konuskan O, Saneoka H, Yoldash KM. 2016a. Evaluation of maize hybrids to terminal drought stress tolerance by defining drought indices. Journal of Experimental Biology and Agricultural Sciences, 4(6): 610-616.

Barutcular C, Dizlek H, El-Sabagh A, Sahin T, Elsabagh M, Islam S. 2016b. Nutritional quality of maize in response to drought stress during grain-filling stages in Mediterranean climate condition. J. Exp. Biol. Agric. Sci., (4): 644-652.

EL Sabagh A, Barutçular C, Saneoka H. 2015. Assessment of drought tolerance maize hybrids at grain growth stage in Mediterranean area. Int. J. Biol. Biomol. Agr. Food. Biotechnol. Eng. (International Science Index), 9(9).

Gomez KA, Gomez AA. 1984. Statistical procedures for agricultural research. John Wiley and Sons. New York. Pp. 680.

Horuz A, Özcan C. 2017. Kireçli toprakta mısır bitkisine (Zea mays evarta) uygulanan borun verim be bor kapsamına etkileri. Bor dergisi, 2(1): 37-42.

Hunt CD, Shuler TR, Mullen LM. 1991. Concentration of boron and other elements in human foods and personel- care products. Journal of American Dietetic Association, 95(5): 558-568.

Ilker E. 2011. Correlation and path coefficient analyses in sweet corn. Turk. J. Field Crops 16(2): 105-107.

Kaur G, Nelson KA. 2015. Effect of foliar boron fertilization of fine textured soils on corn yields. Agronomy 5: 1-18.

Konuskan Ö, Gözübenli H. 2001. İkinci ürün olarak yetiştirilen bazı melez mısır çeşitlerinde bitki sıklığının verim ve verimle ilişkili özelliklere etkisi. Tarla Bitkileri Merkez Araştırma Dergisi, 10(1-2): 50-57.

Konuskan Ö, Konuskan Bozdoğan D, Levia CM. 2017. Effect of foliar boron fertilization on chemical properties and fatty acid compositions of corn (Zea mays L.). REV.CHIM.(Bucharest) 68( 9): 2073-2075.
Konuskan Ö. 2018. Application of boron at early vegetative stage improves the quality as well as productivity of maize (zea mays 1.) in Mediterranean environment. Fresenius Environmental Bulletin, 27(3): 1756-1763.

Kurşun İ, Gürbüz MA, Günay E, Kaya Y, Evci G, Süzer S, Pekcan V. 2006. Bor gübrelemesinin trakya yöresinde ayçiçeği verimi üzerine etkisi. Boron, 1(2): 74-85.

Lordkaew S, Dell B, Jamjod S, Rerkasem B. 2010. Boron deficiency in maize. Plant Soil, 342(1-2): 207-220.

Marchneer H. 1995. Mineral nutrition of higher plants, 2th academic press, new York, 1995.

Nelson KA, Meinhardt CG. 2011. Foliar boron and pyraclostrobin effects on corn yield. Agronomy Journal, 103(5): 1352-1358.

Palta Ç, Karadavut U. 2011. Shoot growth curve analysis of maize cultivars under boron deficiency. The Journal of Animal \& Plant Sciences, 21(4): 696-699.

Seidel EP, Egewarth WA, Piano JT, Egewarth J. 2015. Effect on foliar application rates of calcium and boron on yield and yield attributes of soybean (Glycine max). African journal of Agricultural Research, 10(4); 170-173.

Shagholi SH, Nemati N, Silspur M. 2013. Effect of nitrogen fertilizer and spray the element boron some agronomic traits of corn (Zea mays L.) hybrid (SC704) in Varamin Iran. Annals of Biological Research, 2013, 4 (3):37-40.

Shehzad MA, Maqsood M, Abbas T, Ahmad N. 2016. Foliar boron spray for improved yield, oil quality and water use efficiency in water stressed sunflower. Sains Malasiana, 45(10): 1497-1507.

Soylu S, Topal A, Sade B, Akgün N, Gezgin S, Babaoglu M. 2004. Yield and yield attributes of durum wheat genotypes as affected by boron application in boron-deficient calcareous soils: an evaluation of major Turkish genotypes for boron efficiency. Journal OF Plant Nutrition, 27(6): 1077-1106.

Ulger AC. 1986. Reaktion Verschiedener Mais-Inzuchtlinien und hybryden auf steigendes stickstoffangebot, Dissertation, Hohenheim-Stutgart/ West Germany. p. 83.

Wasaya A, Shabir MS, Hussain M, Ansar M, Aziz A, Hassan W, Ahmad I. 2017. Foliar application of zinc and boron improved the productivity and net returns of maize grown under rainfed conditions of Pothwar plateau. Journal of Soil Science and Plant Nutration, 17(1): 33-45.

Yalçın M, Çimrin KM, Tutuş Y. 2018. Hatay ili Kırıkhan Reyhanlı bölgesi çayır-mera topraklarının besin elementi durumları ve bazı toprak özellikleri ile ilişkileri. KSÜ Tarım ve Doğa Dergisi, 21(3):385-396.

Ziaeayan A H, Majaie M. 2009. Combined effect of zinc and boron on yield and nutrients accumulation in corn. International Journal of Plant Production, 3(3):1735-6814. 